\title{
A Morphometric Study of the Mandibular Foramen in Dry Adult Human Mandibles in a Black Malawian Population
}

\author{
Un Estudio Morfométrico del Foramen Mandibular en Mandíbulas \\ Humanas Adultas Secas en una Población Malauí Negra
}

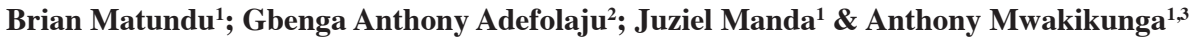

MATUNDU, B.; ADEFOLAJU, G. A.; MANDA,J. \& MWAKIKUNGA, A. A morphometric study of the mandibular foramen in dry adult human mandibles in a black Malawian population. Int. J. Morphol., 39(2):390-395, 2021.

SUMMARY: The inferior alveolar nerve block(IANB) technique is a common technique performed on patients in dental surgery, placement of mandibular implants and other procedures involving the mandible. Precise identification of the mandibular foramen (MF) is essential for dental surgeons to accurately administer local anesthetics. Inaccurate localization of the mandibular foramen may result in IANB failure and injury to neurovascular tissues. Therefore, this study aimed at investigating the precise location of the MF from various anatomical land marks in dry adult human mandibles of Malawian population. The study was conducted on 29 dry adult human mandibles of unknown sex of Malawian origin from the Anatomy Division collection of human skeletons housed in the Biomedical Sciences Department, College of Medicine, University of Malawi. To determine the position of the mandibular foramen, distances from mandibular foramen to anterior margin, posterior margin, mandibular notch, gonial angle and mandibular base using a Vernier caliper were measured. The mean distance of the MF from posterior margin of mandibular ramus was $11.26 \pm 1.22 \mathrm{~mm}$ (right side) and $11.47 \pm$ $1.35 \mathrm{~mm}$ (left side), from the anterior margin $20.85 \pm 3.12 \mathrm{~mm}$ (right side) and $20.85 \pm 3.22 \mathrm{~mm}$ (left side) mandibles. The mean distance between mandibular notch $(\mathrm{MN}$ ) and $\mathrm{MF}$ was $23.87 \pm 2.61 \mathrm{~mm}$ (right side) and $23.53 \pm 2.65 \mathrm{~mm}$ (left side). The mean distance between mandibular base(MB) and MF for the right and left were $28.47 \pm 2.90 \mathrm{~mm}$ and $27.85 \pm 2.99 \mathrm{~mm}$ respectively. The inferior limit of the mandibular foramen was located at $24.69 \pm 3.65 \mathrm{~mm}$ (right side) and $24.25 \pm 2.77 \mathrm{~mm}$ (left side) to the angle (AG) of the mandible. The findings of this study show that the anterior margin mean distance from the MF for both right and left mandibles seem to be bilateral symmetrical suggesting the interpretation that the needle for IANB could be inserted at about $21 \mathrm{~mm}$ from the anterior margin to the MF in an adult of Malawian origin during surgery.

KEY WORDS: Mandible; Mandibular foramen; Inferior alveolar nerve block; Anaesthesia; Malawi.

\section{INTRODUCTION}

In dentistry, the inferior alveolar nerve block (IANB) is the most common technique used to administer local anesthetics to the mandibular teeth, gingiva and lower lip (Shalini et al., 2016). However, there are reports of frequent technique failure and the failure rate is as high as $20 \%$ to 25 $\%$ (Shalini et al.). According to Sastya \& Preeti (2016) the failure rate in this technique could be as high as $45 \%$.The causes of the IANB technique failure are alluded to variations in the location of the mandibular foramen (Russa \& Fabian, 2014) and presence of accessory mandibular foramen through which additional branches of inferior alveolar nerves and vessels course in some individuals (Samanta \& Kharb, 2013). The MF gives the entry point of the inferior alveolar nerve, which is accompanied by inferior alveolar artery and vein. This neurovascular bundle courses through the mandibular canal supplying sensation to the lower teeth, associated gingivae, the mucosa and skin of lower lip and chin. The inferior alveolar nerve exists the mandibular canal through the mental foramen (Drake et al., 2015; Rajkumari et al., 2017; Moore, 2018).

The location of MF is clinically important in osteotomy, orthognathic reconstructive surgery of the mandible, dental implant procedures and anthropometric assessment (Juodzbalys \& Wang, 2010; Lalitha et al., 2016; Rajkumari et al.). The proximity of the anesthetic injection needle to the MF determines the success of the IANB technique. If the hypodermic needle is improperly placed,

\footnotetext{
${ }^{1}$ Department of Biomedical Sciences, Anatomy Division, College of Medicine, University of Malawi, Blantyre, Malawi.

${ }^{2}$ Department of Pre-Clinical Sciences, School of Health Care Sciences, University of Limpopo, Sovenga, South Africa.

${ }^{3}$ School of Anatomical Sciences, University of the Witwatersrand, Johannesburg, South Africa.
} 
the anesthetic may not be properly deposited and will not induce the required anaesthetizing effect on the alveolar nerve. Besides, it may lead to some complications such as hemorrhage, injury to the neurovascular bundle, and necrosis of the mandibular ramus (Sghaireen et al., 2020). The accuracy of the IANB technique is based on thorough anatomical knowledge of the precise location of the mandibular foramen.

Anatomical variations in the location of the MF have been reported in a number of studies worldwide. The variations in the MF location are due to race and growth rate among populations (Russa \& Fabian; Correa et al., 2019). Some studies relate the location of the MF to the occlusal plane (Mbajiorgu, 2000; Russa \& Fabian). Mwaniki \& Hassanali (1992) in their study on localization of mandibular foramen among adult Kenyan Africans have reported that the MF is below the occlusal plane in about $64.6 \%$ and at the level of the occlusal plane in about 31.1 $\%$. This differs from a study by Nicholson (1985) that notes that $75 \%$ of mandibles studied on an East Indian population have the MF below the occlusal plane and $22.5 \%$ are above the occlusal plane. In Tanzanian mandibles, the MF is above the occlusal plane at the mandibular first molar and second premolar reference points (Russa \& Fabian).

Moreover, most of these studies on the mandibular foramen relate its location to the anatomical landmarks such as anterior and posterior margins of mandibular ramus, gonial angle and the lowest point on the mandibular notch (Samanta \& Kharb; Sastya \& Preeti; Shalini et al.). A morphometric study among South African dry mandibles has reported that the MF is always more located on the posterior margin of ramus of mandible than on the anterior region in both males and females (Tshite, 2017). The MF is more situated in the superior part than the inferior part of the mandible, more towards the sigmoid notch than the inferior margin of ramus of the mandible (Tshite). In the light of the foregoing, it is clear that the MF dimensions and location might be population specific even within the same ethnic grouping and region. It was because of this that this study was designed to obtain baseline morphometric data for this population to determine the precise location of the MF from the anterior margin, posterior margin, mandibular notch, mandibular base and gonial angle in adult dry mandibles of black Malawians.

\section{MATERIAL AND METHOD}

This study was conducted in accordance with the Government of Malawi Anatomy Act No.14 of 1990 and was approved by the University of Malawi's College of Medicine Research and Ethics Committee (COMREC) with a clearance number P02/10/872. The study was conducted on adult cadavericdry mandibles obtained from the Anatomy Division Collection of Human Skeletons housed in the Biomedical Sciences Department, College of Medicine, University of Malawi. The sample included only dry mandibles prepared from adult black Malawian cadavers.

A total of 29 dry adult human mandibles of unknown sex, aged 21- 82 years, were studied from the skeletal collection. Malformed and broken bones were excluded from the sample. To precisely locate the mandibular foramen, the following parameters were taken using a sliding Vernier caliper (Fig. 1):
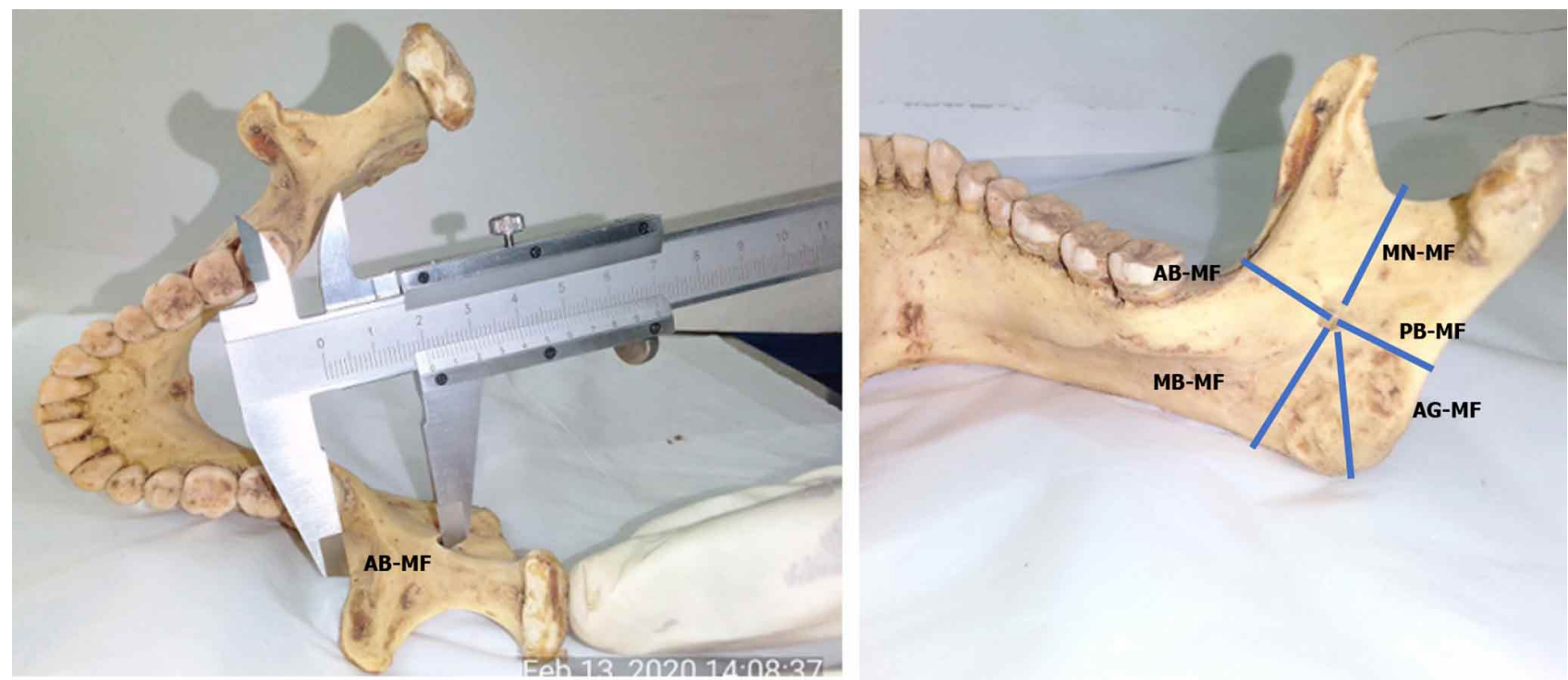

Fig. 1. Measurement of MF from anterior margin (AB-MF), posterior margin (PB-MF), mandibular notch (MN-MF), mandibular base (MB-MF) and gonial angle (AG- MF) 
1. AB-MF- Distance from the midpoint of the anterior margin (AM) of mandibular foramen (MF) to the nearest point on the anterior margin $(\mathrm{AB})$ of mandibular ramus.

2. PB-MF- Distance from the midpoint of the posterior margin (PM) of mandibular foramen (MF) to the nearest point on the posterior margin (PB) of mandibular ramus.

3. MN-MF- Distance from the lowest point of mandibular notch (MN) to the inferior limit of mandibular foramen.

4. AG-MF- Distance from the inferior limit of mandibular foramen to the angle (AG) of the mandible where inferior margin of mandible merges with the posterior margin.

5. Angle of mandible was measured using a goniometer (Fig. 2).

Data analysis. The mean and standard deviation for each distance used to locate the mandibular foramen were calculated separately for both right and left mandibles using Stata. The mean distances of this population were compared with other ethnic groups from previous similar studies. Differences were considered statistically significant when $\mathrm{p}<0.05$.

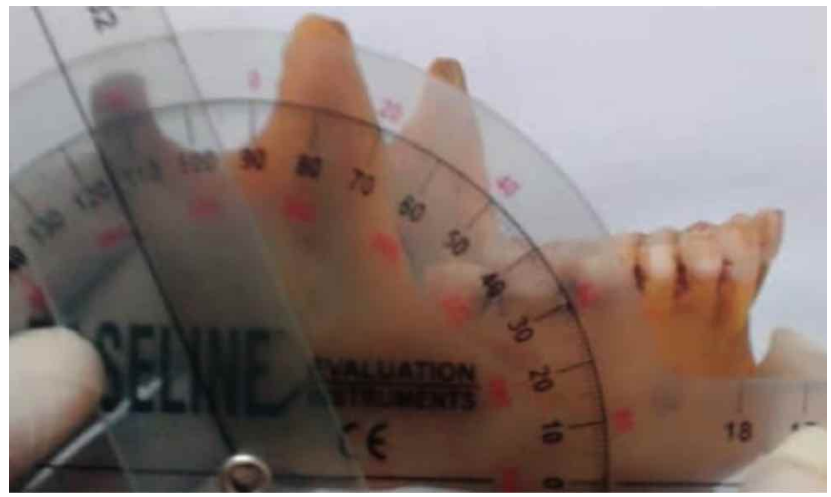

Fig. 2. Anthropometric method used in determination of the angle of the mandible.

\section{RESULTS}

The mean and standard deviation (SD) values of distance of the MF from different landmarks on the right and left side of the mandibles are presented in Tables I and II and Figure 2.

Table I. Distance of mandibular foramen(MF) from various landmarks.

\begin{tabular}{llccc}
\hline Distance & Side & Mean(mm) & $\begin{array}{c}\text { Standard } \\
\text { deviation }(\mathrm{SD})\end{array}$ & $\begin{array}{c}\text { Range }(\mathrm{mm}) \\
\text { Min-Max }\end{array}$ \\
\hline AB - MF & Right & 20.85 & \pm 3.12 & $13-27.5$ \\
& Left & 20.85 & \pm 3.22 & $13.5-28$ \\
PB - MF & Right & 11.26 & \pm 1.22 & $8-13.5$ \\
& Left & 11.47 & \pm 1.35 & $8-14$ \\
MN - MF & Right & 23.87 & \pm 2.61 & $18.5-30$ \\
& Left & 23.53 & \pm 2.65 & $18.5-30$ \\
AG-MF & Right & 24.69 & \pm 3.65 & $19-32$ \\
& Left & 24.25 & \pm 2.77 & $2.05-31$ \\
MB - MF & Right & 28.47 & \pm 2.90 & $23.5-35.5$ \\
& Left & 27.85 & \pm 2.99 & $24-35$ \\
\hline
\end{tabular}

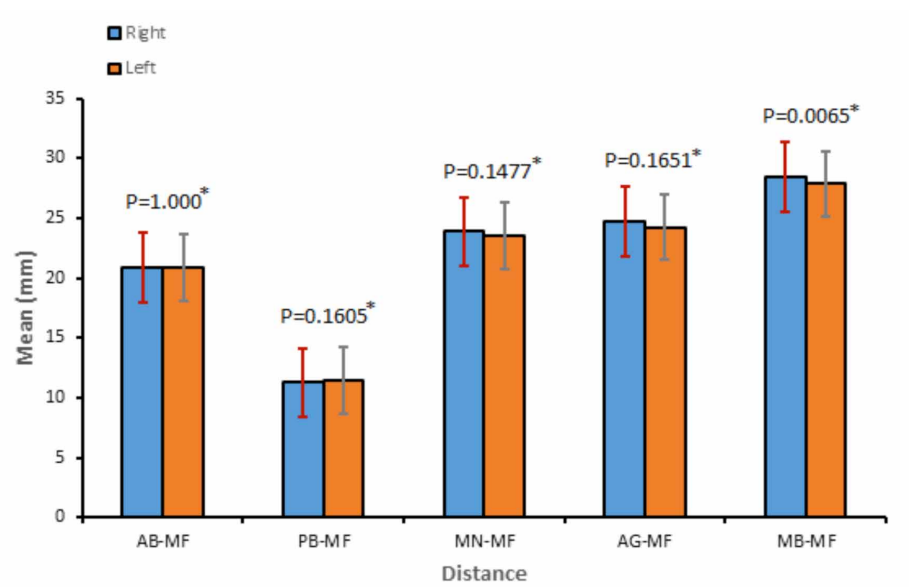

Fig. 3. Descriptive summaries for various distance measurements; from the mandibular foramen to anterior margin of mandible, posterior margin of mandible, mandibular notch, mandibular angle and mandibular base. *P-values for independent samples t-test assessing differences in measurements (Means) between right and left.

The mean distance of the MF from posterior margin of the mandibular ramus was $11.26 \pm 1.22 \mathrm{~mm}$ (right side) and $11.47 \pm 1.35$ $\mathrm{mm}$ (left side), from the anterior margin $20.85 \pm$ $3.12 \mathrm{~mm}$ (right side) and $20.85 \pm 3.22 \mathrm{~mm}$ (left side) mandibles. The mean distance between $\mathrm{MN}$ and $\mathrm{MF}$ was $23.87 \pm 2.61 \mathrm{~mm}$ (right side) and $23.53 \pm 2.65 \mathrm{~mm}$ (left side). The mean distance between MB and MF for the right and left sides were $28.47 \pm 2.90 \mathrm{~mm}$ and $27.85 \pm$ $2.99 \mathrm{~mm}$ respectively. The inferior limit of the mandibular foramen (MF) was located at 24.69 $\pm 3.65 \mathrm{~mm}$ (right side) and $24.25 \pm 2.77 \mathrm{~mm}$ (left side) from the angle (AG) of the mandible. Figure 3 presents the mean distances of MF from the anterior and posterior margins of mandibular ramus, mandibular notch, mandibular base and angle of mandible.

Table II. Angle of the mandible for right and left side.

\begin{tabular}{lll}
\hline Parameter & Right side & Left side \\
\hline Mean $( \pm$ SD) & $116.07^{0 \pm} 4.02$ & $115.75^{0} \pm 4.25$ \\
Min-Max (mm) & $105^{0}-124^{0}$ & $105^{\circ}-126^{0}$ \\
"P" Value & & $P=0.5154$ \\
\hline
\end{tabular}




\section{DISCUSSION}

Antero-posterior dimensions. In this study, a significant difference is observed between the posterior and anterior mean distances (PB-MF) for the right and left mandibles $(\mathrm{P}=0.002)$. The posterior mean distances (PB-MF) for the right and left mandibles are less than the anterior mean distances (AB-MF). This suggests that the MF appears to be located more towards the posterior margin than the anterior margin. Additionally, there is no significant difference between the right and left mean distances of PB-MFand AB-MF ( $>0.05$ ). Similarly, Tshite, Samanta \& Kharb; Sastya \& Preeti; Shalini et al. have asserted that no significant differencein the mean distances of PB-MF and AB-MFis noted between the right and left mandibles. A study by Tshite on black South African dry mandibles established that the mean of AB-MF is $18.8 \mathrm{~mm}$ on the right and $18.9 \mathrm{~mm}$ on the left whereas the mean of PB-MF is $13.7 \mathrm{~mm}$ on the right and $13.4 \mathrm{~mm}$ on the left suggesting that the position of MF on dry bones is more towards the posterior margin of the ramus of the mandible than on the anterior margin. The results from a study of dry mandibles by Samanta \& Kharb, among an Indian population reports that the averagedistance of the MF from the anterior margin of mandibular ramus is $15.72 \pm 2.92 \mathrm{~mm}$ and $16.23 \pm 2.88 \mathrm{~mm}$ right and left side respectively. The posterior margin is 13.29 $\pm 1.74 \mathrm{~mm}$ and $12.73 \pm 2.04 \mathrm{~mm}$ from right and left side respectively. Thus the MF is located more towards the posterior margin than the anterior margin. Furthermore, Shalini et $a l$. note that the mean distance of mandibular foramen from the anterior margin of ramus of mandible is $17.11 \pm 2.74 \mathrm{~mm}$ on the right side and $17.41 \pm 3.05 \mathrm{~mm}$ on the left side; from the posterior margin, it is $10.47 \pm 2.11 \mathrm{~mm}$ on the right side and $9.68 \pm 2.03 \mathrm{~mm}$ on the left side showing that the MF is located more towards the posterior margin.

However, other studies have shown a significant difference in the AB-MF between the right and left mandibles $(p<0.05)$ (Russa \& Fabian). Moreover, the AB-MF mean distance for the present study is generally wider than and in variance with other studies done in Indian populations whose results are several millimeters smaller (Samanta \& Kharb; Shalini et al.).

Comparing the PB-MF mean distances of this study with those of other populations, there is a statistical significant difference $(\mathrm{p}<0.05)$ between the right and left sides. For this reason, observations of the present study suggest that the MF location and morphometrics variation could be population specific. This supports earlier studies that have reported that mandibular dimensions are race and population specific (Ashkenazi et al., 2011). These variations could not only be due to geographical, nutritional and genetic factors, but also different techniques and methodologies used to assess the MF morphometrics (Ashkenazi et al.) and the limitation of the present study due to a small sample size.

Supero-inferior and gonial angle - mandibular foramen dimensions. With regard tothe superior (MN-MF) and inferior (MB-MF) dimensions, it has been established in the present study that the mean distance between MN and MF for the right and left is less than the mean distance between MB and MF for the right and left mandibles suggesting the interpretation that the MF is located more towards the mandibular notch than the mandibular base. Likewise, Shalini et al., Mbajiorgu, and Tshite found similar results in that the $\mathrm{MF}$ is located more towards the mandibular notch than the mandibular base.

Also, a significant difference $(\mathrm{p}<0.05)$ is observed in the MN-MF mean distance between the present study and other studies (Shalini et al.; Mbajiorgu; Tshite). Shalini et al. found that the MN-MF mean distance to be $21.74 \pm 2.74 \mathrm{~mm}$ and $21.92 \pm 3.33 \mathrm{~mm}$ for the right and left sides respectively. They also reported the MB-MF mean distances of $22.33 \pm 3.32 \mathrm{~mm}$ for right and $25.35 \pm 4.5 \mathrm{~mm}$ for the left side. Tshite also found that the MF is situated more towards the superior margin of the ramus of the mandible than the inferior margin.

According to Tshiste (2017) the MN-MF was shown to be $20.13 .0 \mathrm{~mm}$ and $20.03 .1 \mathrm{~mm}$ on the right and left sides respectively. He recorded $22.9 \mathrm{~mm}$ on the right and $22.7 \mathrm{~mm}$ on the left as mean distances from MF to the Gonial angle which he regarded as the most inferior point of the mandible. Whereas for adult black dry Zimbabwean mandibles, a mean distance of $22.50 \pm 0.50 \mathrm{~mm}$ and $28.44 \pm 0.65 \mathrm{~mm}$ from MN and AG to MF were recorded respectively (Mbajiorgu). For a Tanzanian population, Russa \& Fabian reports that the mean distance from MF to the MN to be $21.54 \pm 3.02 \mathrm{~mm}$ and 20.70 $\pm 2.98 \mathrm{~mm}$ on the right and left side respectively. They established $26.23 \pm 3.95 \mathrm{~mm}$ and $25.68 \pm 4.03 \mathrm{~mm}$ as AG-MF mean distance for the right and left side respectively. The current study found $24.69 \pm 3.65 \mathrm{~mm}$ and $24.25 \pm 2.77 \mathrm{~mm}$ as the average distances from MF to the mandibular angle for right and left side; with the right demonstrating a higher reading. An independent samples t-test reveals that there is no significant difference the right and left sides for AG-MF $(\mathrm{p}=0.1651)$.

Besides, there is no significant difference between the right and the left sides for MN-MF ( $\mathrm{p}=0.1477)$ and MB$\mathrm{MF}(\mathrm{p}=0.065)$ in the current study.

Comparing to previous studies done in Tanzania and South African black populations an Independent samples ttest showed that there is a no statistically significant 
MATUNDU, B.; ADEFOLAJU, G. A.; MANDA, J. \& MWAKIKUNGA, A. A morphometric study of the mandibular foramen in dry adult human mandibles in a black Malawian population. Int. J. Morphol., 39(2):390-395, 2021

Table III. Comparison of mean distance of the mandibular foramen from various landmarks between the present study and other studies.

\begin{tabular}{|c|c|c|c|c|c|c|c|c|}
\hline $\begin{array}{l}\text { Dist ance } \\
\text { and angles }\end{array}$ & Side & $\begin{array}{l}\text { Present study } \\
\mathrm{N}=29\end{array}$ & $\begin{array}{l}\text { Russa \& } \\
\text { Fabian } \\
\text { (Tanzania) }\end{array}$ & $\begin{array}{l}\text { Samanta \& } \\
\text { Kharb } \\
\text { (India) }\end{array}$ & $\begin{array}{l}\text { Mbajiorgu } \\
\text { (Zimbabwe) }\end{array}$ & $\begin{array}{l}\text { Shalini et al. } \\
\text { (India) } \\
\mathrm{N}=204\end{array}$ & $\begin{array}{l}\text { Tshite } \\
\text { (South } \\
\text { Africa) }\end{array}$ & $\begin{array}{l}\text { (Lima et al., } \\
2016) \\
\text { (Brazil) }\end{array}$ \\
\hline \multirow[t]{4}{*}{$\begin{array}{l}\mathrm{AB}-\mathrm{MF} \\
(\mathrm{mm})\end{array}$} & Right & $20.85 \pm 3.12$ & $19.88 \pm 3.16$ & $15.72 \pm 2.92$ & $\begin{array}{l}18.95 \pm 0.41 \\
(0.0000)\end{array}$ & $\begin{array}{l}17.11 \pm 2.74 \\
(0.0000)\end{array}$ & $\begin{array}{l}18.8 \pm 2.4 \\
(0.0014)\end{array}$ & $\begin{array}{l}18.33 \pm 3.76 \\
(0.0002)\end{array}$ \\
\hline & & & $(0.1056)$ & $(0.0000)$ & & & & \\
\hline & Left & $20.85 \pm 3.22$ & $20.19 \pm 2.603$ & $16.23 \pm 2.88$ & & $\begin{array}{l}17.41 \pm 3.05 \\
(0.0000)\end{array}$ & $\begin{array}{l}18.9 \pm 2.5 \\
(0.0029)\end{array}$ & $\begin{array}{l}19.04 \pm 3.56 \\
(0.0053)\end{array}$ \\
\hline & & & & $(0.0000)$ & & & & \\
\hline \multirow[t]{2}{*}{$\begin{array}{l}\mathrm{PB}-\mathrm{MF} \\
(\mathrm{mm})\end{array}$} & Right & $11.26 \pm 1.22$ & $\begin{array}{l}12.69 \pm 2.18 \\
(0.0000)\end{array}$ & $\begin{array}{l}13.29 \pm 1.74 \\
(0.0000)\end{array}$ & $\begin{array}{l}14.30 \pm 0.35 \\
(0.0000)\end{array}$ & $\begin{array}{l}10.47 \pm 2.11 \\
(0.0017)\end{array}$ & $\begin{array}{l}13.7 \pm 2.0 \\
(0.0000)\end{array}$ & $\begin{array}{l}14.31 \pm 2.85 \\
(0.0000)\end{array}$ \\
\hline & Left & $11.47 \pm 1.35$ & $\begin{array}{l}12.65 \pm 2.57 \\
(0.0001)\end{array}$ & $\begin{array}{l}12.73 \pm 2.04 \\
(0.0000)\end{array}$ & & $\begin{array}{l}9.68 \pm 2.03 \\
(0.0000)\end{array}$ & $\begin{array}{l}13.4 \pm 2.0 \\
(0.0000)\end{array}$ & $\begin{array}{l}14.78 \pm 3.67 \\
(0.0000)\end{array}$ \\
\hline \multirow[t]{2}{*}{$\begin{array}{l}\mathrm{MN}-\mathrm{MF} \\
(\mathrm{mm})\end{array}$} & Right & $23.87 \pm 2.61$ & $\begin{array}{l}21.54 \pm 3.02 \\
(0.0000)\end{array}$ & $\begin{array}{l}22.70 \pm 3.00 \\
(0.0222)\end{array}$ & $\begin{array}{l}22.50 \pm 0.50 \\
(0.0006)\end{array}$ & $\begin{array}{l}21.74 \pm 2.74 \\
(0.0001)\end{array}$ & $\begin{array}{l}20.1 \pm 3.0 \\
(0.0000)\end{array}$ & $\begin{array}{l}21.35 \pm 3.59 \\
(0.0000)\end{array}$ \\
\hline & Left & $23.53 \pm 2.65$ & $\begin{array}{l}20.70 \pm 2.98 \\
(0.0000)\end{array}$ & $\begin{array}{l}22.27 \pm 2.92 \\
(0.0164)\end{array}$ & & $\begin{array}{l}21.92 \pm 3.33 \\
(0.0029)\end{array}$ & $\begin{array}{l}20.0 \pm 3.1 \\
(0.0000)\end{array}$ & $\begin{array}{l}21.05 \pm 3.09 \\
(0.0000)\end{array}$ \\
\hline \multirow[t]{2}{*}{$\begin{array}{l}\mathrm{AG}-\mathrm{MF} \\
(\mathrm{mm})\end{array}$} & Right & $24.69 \pm 3.65$ & $\begin{array}{l}26.23 \pm 3.95 \\
(0.0312)\end{array}$ & $\begin{array}{l}21.54 \pm 2.92 \\
(0.0001)\end{array}$ & $\begin{array}{l}28.44 \pm 0.65 \\
(0.0000)\end{array}$ & & $\begin{array}{l}22.9 \pm 3.7 \\
(0.0132)\end{array}$ & \\
\hline & Left & $24.25 \pm 2.77$ & $\begin{array}{l}25.68 \pm 4.03 \\
(0.094)\end{array}$ & $\begin{array}{l}21.13 \pm 3.43 \\
(0.0000)\end{array}$ & & & $\begin{array}{l}22.7 \pm 3.7 \\
(0.0211)\end{array}$ & \\
\hline \multirow[t]{2}{*}{$\begin{array}{l}\mathrm{MB}-\mathrm{MF} \\
(\mathrm{mm})\end{array}$} & Right & $28.47 \pm 2.90$ & & & & $\begin{array}{l}22.33 \pm 3.32 \\
(0.0000)\end{array}$ & & $\begin{array}{l}27.88 \pm 4.92 \\
(0.2867)\end{array}$ \\
\hline & Left & $27.85 \pm 2.99$ & & & & $\begin{array}{l}25.35 \pm 4.5 \\
(0.0001)\end{array}$ & & $\begin{array}{l}27.26 \pm 4.75 \\
(0.2954)\end{array}$ \\
\hline \multirow{2}{*}{$\begin{array}{l}\text { Mandibular } \\
\text { Angle } \\
\text { (degrees) }\end{array}$} & Right & $116.07 \pm 4.12$ & & & & $\begin{array}{l}117.47 \pm 4.95 \\
(0.0000)\end{array}$ & & \\
\hline & Left & $115.76 \pm 4.24$ & & & & $\begin{array}{l}117.47 \pm 5.88 \\
(0.000)\end{array}$ & & \\
\hline
\end{tabular}

Distances are in millimeters while angles are in degrees. P-values are displayed in parentheses. Differences were considered statistically significant when $\mathrm{p}<0.05$.

difference in AG-MF mean for both right and left sides ( $p>0.05)$ (Table II). However, there is a statistical significant differencein AG-MF distance for both right and left sides to that of an Indian population studied by Samanta \& Kharb (Table III). In the present study, if we consider the AG-MN and MB-MN dimensions, still the MF is situated more towards the MN. However, the finding of the present study differs from the study by Samanta \& Kharb, which shows that the MF is located more towards the inferior margin than the mandibular notch.

Angle of mandible. A study by Agrawal \& Kanwar (2018) found that angle of mandible in 29 male and 23 female mandibles of right side, mean and standard deviation is 122.240 \pm 6.71 and $124.610 \pm 5.33$ respectively and "P" value is 0.1734 . Similarly, in case of left side mean and SD is $121.590 \pm 6.65$ and $124.170 \pm 5.87$ respectively and "P" value is 0.1489 . Shalini et al. found that the angle of the mandible was 117.470 \pm 4.95 on the right side and $117.470 \pm 5.88$ on the left side. There was no statistically significant difference between the angles of the mandible on the right and left sides $(\mathrm{P}>0.05)$. This is in agreement with the results of the present study in which there is no significant difference between the right and left angle measurements $(p=0.5154)$.The mean Gonial angle measurements in the present study were $116.070 \pm 4.02$ and $115.750 \pm 4.25$ for right and left sides respectively, with an overall range of $1050-1260$.

\section{CONCLUSION}

The current study has provided the mean distances of the MF from the anterior margin, posterior margin, mandibular notch, mandibular angle and mandibular base. The asymmetric dimensions of the MF appear to be population specific which may suggest the interpretation that this could be geographical, nutritional and genetic factors. Besides, the anterior margin mean distance from the MF for both right $(20.85 \pm 3.12 \mathrm{~mm})$ and left $(20.85 \pm 3.22 \mathrm{~mm})$ mandibles seem to be bilateral symmetrical suggesting that clinically the anesthetic for IANB could be deposited at about $21 \mathrm{~mm}$ from the anterior margin to the MF in an adult of black Malawian origin during surgery. 
MATUNDU, B.; ADEFOLAJU, G. A.; MANDA, J. \& MWAKIKUNGA, A. Un estudio morfométrico del foramen mandibular en mandíbulas humanas adultas secas en una población malauí negra. Int. J. Morphol., 39(2):390-395, 2021.

RESUMEN: La técnica de bloqueo del nervio alveolar inferior (IANB) es una técnica común que se realiza en pacientes en cirugía dental, colocación de implantes mandibulares y otros procedimientos que involucran la mandíbula. La identificación precisa del foramen mandibular (MF) es esencial para que los cirujanos dentistas administren con precisión anestésicos locales. La localización inexacta del foramen mandibular puede resultar en una falla de la IANB y lesión de los tejidos neurovasculares. Por lo tanto, este estudio tuvo como objetivo investigar la ubicación precisa de la MF de varias marcas anatómicas en las mandíbulas humanas adultas secas de la población de Malawi. El estudio se llevó a cabo en 29 mandíbulas humanas adultas secas de sexo desconocido de origen malauí de la colección de esqueletos humanos de la División de Anatomía del Departamento de Ciencias Biomédicas de la Facultad de Medicina de la Universidad de Malawi. Para determinar la posición del foramen mandibular, se midieron las distancias desde el foramen mandibular hasta el margen anterior, margen posterior, incisura mandibular, ángulo gonial y base mandibular utilizando un calibre Vernier. La distancia media del MF desde el margen posterior de la rama mandibular fue de 11,26 $\pm 1,22 \mathrm{~mm}$ (lado derecho) y $11,47 \pm 1,35 \mathrm{~mm}$ (lado izquierdo), desde el margen anterior 20,85 $\pm 3,12 \mathrm{~mm}$ (lado derecho) y 20,85 $\pm 3,22 \mathrm{~mm}$ (lado izquierdo) lado) mandíbulas. La distancia media entre la muesca mandibular (MN) y MF fue de 23,87 $\pm 2,61 \mathrm{~mm}$ (lado derecho) y 23,53 $\pm 2,65 \mathrm{~mm}$ (lado izquierdo). La distancia media entre la base mandibular (MB) y MF para la derecha y la izquierda fue de $28,47 \pm 2,90 \mathrm{~mm}$ y $27,85 \pm 2,99 \mathrm{~mm}$, respectivamente. El límite inferior del foramen mandibular se ubicó a 24,69 $\pm 3,65 \mathrm{~mm}$ (lado derecho) y $24,25 \pm 2,77 \mathrm{~mm}$ (lado izquierdo) del ángulo (AG) de la mandíbula. Los resultados de este estudio muestran que la distancia media del margen anterior desde el MF para las mandíbulas derecha e izquierda parece ser simétrica bilateral, lo que sugiere la interpretación de que la aguja para IANB podría insertarse a unos $21 \mathrm{~mm}$ del margen anterior al MF en una adulto de origen malauí durante la cirugía.

PALABRAS CLAVE: Mandíbula; Foramen mandibular; Bloqueo del nervio alveolar inferior; Anestesia; Malawi.

\section{REFERENCES}

Agrawal, R. \& Kanwar, R. Morphometric study of dry adult human mandible using minimum ramus breadth and mandibular angle in Mahakaushal Region. Glob. J. Res. Anal., 7(5):46-8, 2018.

Ashkenazi, M.; Taubman, L. \& Gavish, A. Age-associated changes of the mandibular foramen position in anteroposterior dimension and of the mandibular angle in dry human mandibles. Anat. Rec. (Hoboken), 294(8):1319-25, 2011

Correa, S.; Lopes Motta, R. H. L.; Silva, M. B. F.; Figueroba, S. R.; Groppo, F. C. \& Ramacciato, J.C. Position of the mandibular foramen in different facial shapes assessed by cone-beam computed tomography - A crosssectional retrospective study. Open Dent. J., 13:544-50, 2019.
Drake, R. L.; Vogl, W.; Mitchell, A. W. M. \& Gray, H. Gray's Anatomy for Students. 3rd ed. Philadelphia, Churchill Livingstone/Elsevier, 2015.

Juodzbalys, G. \& Wang, H. L. Identification of the mandibular vital structures: practical clinical applications of anatomy and radiological examination methods. J. Oral Maxillofac. Res., 1(2):e1, 2010.

Lalitha, B.; Sridevi, N. S. \& Rao, E. K. V. Morphometric analysis of mandibular foramen in dry adult human mandibles. Int. J. Sci. Stud., 4(4):20-2, 2016.

Lima, F. J. C.; Oliveira Neto, O. B.; Barbosa, F. T. \& Sousa-Rodrigues, C. F. Location, shape and anatomic relations of the mandibular foramen and the mandibular lingula: a contribution to surgical procedures in the ramus of the mandible. Oral Maxillofac. Surg., 20(2):177-82, 2016.

Mbajiorgu, E. F. A study of the position of the mandibular foramen in adult black Zimbabwean mandibles. Cent. Afr. J. Med., 46(7):184-90, 2000.

Moore, K. L.; Agur, A. M. R. \& Dalley II, A. F. Clinically Oriented Anatomy. 8th ed. Philadelphia, Wolters Kluwer, 2018.

Mwaniki, D. L. \& Hassanali, J. The position of mandibular and mental foramina in Kenyan African mandibles. East Afr. Med.J., 69(4):210-3, 1992.

Nicholson, M. L. A study of the position of the mandibular foramen in the adult human mandible. Anat. Rec., 212(1):110-2, 1985.

Rajkumari, K.; Nongthombam, S. S.; Chongtham, R. S.; Huidrom, S. D.; Tharani, P. \& Sanjenbam, S. D. A morphometric study of the mandibular foramen in dry adult human mandibles - A study in RIMS, Imphal. IOSR J. Dent. Med. Sci., 16(12):39-45, 2017.

Russa, A. D. \& Fabian, F. M. Position of the mandibular foramen in adult male Tanzania mandibles. Ital. J. Anat. Embryol., 119(3):163-8, 2014.

Samanta, P. P. \& Kharb, P. Morphometric analysis of mandibular foramen and incidence of accessory mandibular foramina in adult human mandibles of an indian population. Rev. Argent. Anat. Clin., 5(2):60-6, 2013.

Sastya, A. \& Preeti. Study of mandibular foramen from different bony landmarks in dry human mandibles. Int. J. Sci. Res., 10(5):40-3, 2016.

Sghaireen, M. G.; Srivastava, K. C.; Shrivastava, D.; Ganji, K. K.; Patil, S R.; Abuonq, A.; Mousa, M. A.; Dar-Odeh, N.; Sghaireen, G. M.; Kamal, M.A.; et al. ACBCT based three-dimensional assessment of mandibular posterior region for evaluating the possibility of bypassing the inferior alveolar nerve while placing dental implants. Diagnostics (Basel), 10(6):406, 2020.

Shalini, R.; RaviVarman, C.; Manoranjitham, R. \& Veeramuthu, M. Morphometric study on mandibular foramen and incidence of accessory mandibular foramen in mandibles of south Indian population and its clinical implications in inferior alveolar nerve block. Anat. Cell Biol., 49(4):241-8, 2016.

Tshite, K. Location of Mandibular foramen on Mandibles of adult black South African population: a morphometric analysis and investigation into possible radiographic correlation. Degree of Masters of Science in Dentistry. Johannesburg, Faculty of Health Sciences, University of the Witwatersrand, 2017. Available from: http://wiredspace.wits.ac.za/ bitstream/handle/10539/23310/2017\%20 M Sc \% 20 Final\%20Report.pdf?sequence $=1 \&$ isAllowed $=\mathrm{y}$

Corresponding author:

Adefolaju Gbenga Anthony

Department of Pre-Clinical Sciences,

University of Limpopo,

Private Bag $\times 1106$, Sovenga 0727 ,

SOUTH AFRICA

\section{E-mail: gbenga.adefolaju@ul.ac.ac.za anton.ul2016@gmail.com}

Received: 31-10-2020

Accepted: 12-12-2020 